\title{
Inside The Gates: First-Generation Students Finding Their Way
}

\author{
Barry Checkoway ${ }^{1}$ \\ ${ }^{1}$ The University of Michigan, USA \\ Correspondence: Barry Checkoway, The University of Michigan, USA. E-mail: barrych@umich.edu
}

Received: June 15, 2018

Accepted: July 13, $2018 \quad$ Online Published: August 20, 2018

doi:10.5539/hes.v8n3p72

URL: https://doi.org/10.5539/hes.v8n3p72

\begin{abstract}
This paper examines what first-generation students face when coming inside the gates of higher education for the first time, an experience which, without preparation by them and their institution, can disorient them to a level of anxiety which affects their learning. The paper identifies issues arising when they are trying to find their way, such as choosing courses whose content feels foreign, and finding professors who can communicate with them in ways which they understand. It draws upon a review of the literature, and the experiences of the author as a first-generation student and, subsequently, a professor.
\end{abstract}

Keywords: higher education, first-generation students, institutional change

\section{Introduction}

What do first generation college students encounter when coming inside the gates of higher education? What can colleges do to engage and empower them? What can students themselves do?

First-generation students come inside the gates of higher education for the first time, only once. If they and their institution are unprepared for them, this experience can disorient them to a level of anxiety which affects their learning. The paper identifies some of the issues arising when they are trying o find their way, such as choosing ourses whose content and pedagogy fit their social situation, and finding professors who can communicate with students who are different from themselves.

"First gens" are increasing in higher education, and student affairs professionals are establishing social services with their well-being in mind. But students attend college primarily for an academic experience, and because they are the first, they know relatively little about crossing the threshold into the "academic unknown."

Recent literature on first gens tends to emphasize their characteristics, such as race or class; or access to higher education, such as completing applications and finding financial aid, but not their experience in choosing courses or meeting professors for the first time. Yet, if they are limited in their ability to find courses or professors that fit their situation, then surely this will affect their well-being from the start.

This paper is about the transition to college by students who are arriving for the first time. A student can only start for the first time, once, and if the start is horrifying, it can easily affect the entire experience.

As a first-generation student, I remember how exciting it was to arrive on campus, and how difficult it was to "feel different" and "out of place." I knew nothing about choosing courses or meeting professors, and wondered if I would do well enough to make it in the institution. My university provided an orientation, but failed to recognize the distinct, and difficult, transition of first generation students.

This paper examines some of what first-generation students face when coming "inside the gates." It draws upon my review of the literature on the subject, and my own experiences as a student and, subsequently, a professor.

\section{First-generation Students}

First generation students are the first in their immediate family to attend college. Although they come from various economic backgrounds and social identities, they tend to be lower-income and minority students of color, often from economically-disinvested and racially-segregated areas whose "sending schools" have fewer resources than those in higher-income areas (Ishitani, 2006).

First-gens are increasing in higher education, and can be expected to increase in the years ahead. More financial aid is available than ever before and, as students of African, Asian, and Latin American descent become the majority, they will challenge the institutions to build their capacity (Saenz, Hurtado, Barrera, Wolf, \& Young, 
2007).

First gens come to college with special strengths (Gamson \& Gardner, 2011; Inman \& Mays, 1999; Kahlenberg, 2004). They have recognized the importance of higher education, and accomplished a great deal to get themselves into college. They have faced economic problems in their everyday lives, and faced obstacles because of what their parents are paid, and the color of their skin (Gofen, 2009; Jenkins, 2013).

It might seem strange to refer to these experiences --- such as growing up in disinvestment and segregation --- as strengths. But because they are the first in their families and have been forced to deal with rhea inequalities of the social structure, they have expertise which is lacking higher-income legacy students who come from families have attended college for years and whose primary contact with low income minorities of color has been from reading about them in books (Atherton, 2014; Golden, 2006; Lohfink \& Paulson, 2005).

Perhaps a better way to refer to them is in terms of the "cultural wealth" with which they come to college. They come with special experiences and expertise of their own. They come with advanced abilities to solve problems and navigate institutions which are not of their making, and from which they learn about social inequalities in society. If educators were to view these as forms of wealth, they might choose to build upon rather than remediate them (Yosso, 1995).

Some first gens come through the gates and experience a cultural shock from entering a new world. They are unfamiliar with the grounds and buildings, and wonder how they will find their way around. They see other people who are different from themselves, and wonder if they are in the right place. They feel self-conscious about their social class and racial-ethnic background, and are stunned by the whiteness of the place. (Cushman, 2007; DeWalt, 2011).

Other first gens wonder whether it is fair for them to be attending college while their parents are struggling financially at home, for which they feel guilty. They worry about paying for college and finding their way, but cannot turn to their parents for funds or for information from experience Banks-Santill, 2014; Coarrubias et al., 2015).

Then, they meet other students, attend classes, and encounter a professor for the first time. They are high-achievers, but wonder if they will have what it takes to succeed and what will happen to them if they don't. If they cannot adjust or concentrate on their courses, their encounters with faculty and higher income students might exacerbate their doubt. If their doubt is deep enough, their studies will suffer (Cushman, 2007; Mehta, Newbold \& O'Rourke, 2011).

It is almost as if first gens have entered a new village from outside, and encountered Kafka's castle, which is "vast, remote, and inaccessible." The castle is enshrouded in a cloudy mist. They know that something is happening but cannot understand what it is. They know that other people are there, but cannot grasp what they are doing or what they are saying (Baldwin, 2011; Schultz, 2014).

If earlier efforts are a predictor, however, most first gens will summon up the same resources --- determination, persistence, perseverence, resilience, and grit --- that got them there (Fenstress \& Colby, 2011; Gibbons, Rhinehart \& Hardin, 2016; Matthews \& Kelly, 2007; Somers \& Woodhouse \& Cofer, 2004). They will differ in their ability to adjust, but most of them will eventually succeed (Blackwell \& Pinder, 2014; Padget, Johnson \& Pascarella, 2012; Martin \& Paulsen, 2005; Pierson \& Wolniak, 2004).

First gens are a group, of a certain kind, but usually view themselves as individuals rather than as members of a group that share common concerns around which they can organize. They share "first generation student" as a term used by the college, but have differences among them and will not interact collectively until someone brings them together.

Perhaps it is more accurate to refer to them as "liminal," a group whose members "stand at the threshold," but who have not restructured their identity or transitioned to the status they will hold when their group formation is complete. If their new experience takes hold, their education can create an entirely new --- and transformational --- understanding of the world.

\section{Bridging Programs}

Some first gens participate in bridging programs and social services designed to remediate their deficiencies and ease their transition.

In a typical program, they arrive earlier and live in a residence hall. They are tested in reading and take workshops on writing term papers. They learn about class attendance, time management, and counseling and psychological services (Moore et al., 2007). From their first days, these programs are helping them adjust to, but 
not necessarily change, the institution.

Bridging programs are directed by professionals who assume that they have attended high schools which provide inadequate preparation and that they are unfamiliar with college life. They assume that they will feel different from "normal students" and that this might put them "at risk" in the absence of activities to the contrary (Strayhorn, 2010). They thus organize activities with them in mind, such as "welcome weekend," or "community service day.," or "backpacking adventure." Students usually like the attention they receive, especially making new friends.

Studies show that the programs help them with their social adjustment in their first semester, but usually have little effect on their subsequent academic experience (Ackermann, 1991; Cabrera, Minor \& Milem, 2013; Clauss-Ehlers \& Wibrowski, 2007; Hrabowski, 2005; Inkelas, Daver, Voght \& Leinard, 200; Jehangir, Williams, \& Jeske, 2012; Stewart, 2006).

Bridging programs are like assimilation agencies for new immigrants entering a foreign land. First gens are the first in their families, and the programs provide them with some of what they need to assimilate into the life of the natives. They try to prepare them for moving among them, acquiring a new language, learning a new culture and, when assimilation is successful, becoming indistinguishable from the natives. Assimilation agencies have helped "new immigrants" for years.

Assimilation is a recurrent theme in American society which teaches that crossing boundaries can be perilous, such as when a student of color is denied entrance to white sororities, or a lower income student is shunned in the cafeteria by higher income ones (Gordon. 1964).

This is not to suggest that first-gens cannot cross over to another side of society, a rags-to-riches theme, such as in the Horatio Alger books in which Ragged Dick, a young working class boy, struggles against poverty and learns how to achieve upper-class respectability, under the guidance of a wealthy benefactor; or in The Rise of David Levinsky, in which a Jewish boy finds that the only way to gain an American identity is to hide his true identity, the center of which is his religion, which he does by moving from a Talmudic student in a shtetl, to a tradesman in a New York ghetto, to a successful American businessman in the garment district.

Or, there is My Fair Lady, in which a professor takes Eliza Doolittle, a poor flower girl, and teaches her English, dresses her smartly, and helps her gain acceptance into high society. When the experiment is over, however, the professor abandons her, she feels used and alone, lashes out at him, and leaves the professor mystified by her ingratitude. These characters are rags-to-riches; they are exceptional people; and even when they make it, their journey is perilous.

Bridging programs also might be likened to special education programs which construct first gens as, say, children with learning disabilities or young people with psychological problems. The assumption is that when special needs children have separate programs designed for them, they are more likely to move into normal society.

But these programs also have critics who argue that they label them in harmful ways and treat them as different from normal students Studies show that while the tracking of special education students is relatively harmless in the earlier grades, that when older ones are treated as special, they are likely to accept others' definition of themselves as a "deficit group" that requires professional services to succeed (Giese, 2017).

There are two views of first gens in higher education. The first view is "first generation students as deficits" in which they are low-income and students of color, who are less prepared for college than higher income students, and who require remediation to succeed (White, 2016).

The second view is "first generation students as resources" who have faced economic inequalities and racial discrimination, and have surmounted obstacles to get themselves into college. They come with high motivation and problem-solving skills which enable them to outperform students who come from privilege (Atherton, 2014; Garrison \& Gsrdner, 2012; Green 2016; Inman \& Maynard, 1999; Kahlenberg, 2004; Machias, 2013).

At its worst, bridging programs treat students as deficits who then think of themselves in this way. The self-fulfilling prophecy is when the definition of a situation as real becomes real in its consequences due to the simple fact that that prediction was made. If you define first gens in a way, the definition becomes true in its consequences, although the cycle can be broken.

Bridging programs are positioned to treat these students as trailblazers, blazing a trail for others to follow. Treating them thus can mean a great deal to them, but these programs --- which are largely about social development --- are not necessarily helpful in taking their first courses (McMurray \& Sorrells, 2004). 


\section{Taking Courses}

First-generation students want courses that are "culturally relevant," a pedagogy in which teachers have cultural competence and students relate content to their cultural context.

Like other students, first generation students have knowledge from their experience, and if their sending schools do not prepare them or their professors, then then the students will experience a cultural mismatch.

This is not to suggest that professors should dumb down to first-generation students, or hold back from pushing them across their learning edge --- which is part of what college should be about --- but rather that professors should know enough about their students to know when their pushing is causing panic. In the first semester of college, when many first-generation students are especially fragile, they need some sort of content --- that is, something, anything --- that is familiar to them. There are exceptional professors who know how to handle this, but they are not typical, and most professors do not think that this is their work.

In the first semester, most college students take foundation courses with content which faculty have decided everyone should have, such as natural sciences, social sciences, mathematics, and humanities. The idea is that students should gain broad knowledge of the world, in addition to special knowledge in their fields of interest.

In humanities, for example, foundation courses usually focus on Western Civilization, such as the classics by Plato, Aristotle, Milton, Shakespeare, Freud, and Marx. The classics represent a master narrative which draws upon western civilization as a way for students to make sense of the world.

College students should have courses that complement their cultural context and that provide a foundation on which to build their education. However, all students do not come from the same culture.

First generation students are usually (but not always) from the lower economic class, whereas legacy students are usually higher in economic class, and class differences like these are problematic. They are usually (but not always) minorities of color, and when they enter primarily white institutions, prejudice and discrimination can cause stress that affects their health, well-being, and ability to concentrate.

Low income and minority students of color can learn a great deal from reading the classics of Western Civilization, but there is no good pedagogical or epistemological reason they should be required to read them in the first semester, and there are various good reasons why they might better start with courses that are closer to their cultural background

Low-income students of color are born into a society whose inequalities are already in place. Some (but not all) of them learn how to cope with the cycle of socialization, which includes patterns of prejudice, discrimination, dominance, subservience, and other forms of oppression which were there when they arrived.

When frost generation students come to college from a sending school which provides poor preparation, and are immediately required by professors to take courses that the professors themselves took in college, it is no surprise when they suffer a loss of self-esteem because of the cultural mismatch. It is ironic when professors view liberal arts education to transform lower income students into a higher class --- as the professor did with the flower girl --- when the students are anxious about what the professors are trying to do to them (Morales, 2011).

When students are required to take courses about a world which is foreign, there is reason to expect the requirements --- which well-meaning professors think will be good for them --- will exacerbate the alienation they already experience when forced to take courses outside their experience (Allessandra \& Nelson, 20050.

Research shows that when incoming first-generation students discuss social class and class differences, and the struggles and successes of themselves and other students like them, they learn about how their personal experiences and social environment have affected them. When these students start to realize that these experiences originate in a social structure of which they are part, these ideas can establish an intellectual foundation and anchor any subsequent learning (Conlry \& Hamlin, 2009; Stephens et al., 2013, 2014).

Simply stated, students are on more familiar ground, they are more likely to think of themselves as competent and resourceful, and to develop relationships that contribute to, rather than reduce, their psychosocial well-being.

For low income and minority students of color, it is possible to imagine these illustrative courses as a new core for their education:

- Consciousness-Raising, about the process through which a person views himself as an isolated, accepts others' definitions of him as deficient, and believes that there is nothing he can do to change things. Then he forms a group, discuss the root causes of their problems and the institutions that cause them, question the authorities that define and dominate, grow in confidence, and act to change the situation. 
- Intergroup Dialogue, enabling them to learn about their social identities, differences in power and privilege, and patterns of prejudice and discrimination which affect them. They learn how to talk openly about race and class with others who are different from themselves, respond to stereotypes and triggers from issues, and how to go from intergroup dialogue to social change.

- Social Class, including class differences and social inequalities, formation of upper class culture, the role that it plays in the distribution of power, its effects on the lower classes, and what it would take for them to view themselves as a group and challenge the present distribution of power.

- Leadership for Change, in which they learn how to express goals, identify issues, develop constituencies and allies, and employ actions that influence implementation. Special emphasis is placed on various strategies, such as organizing for political action, planning successful programs, and how advocate on the issues.

- Social Justice in Higher Education, learning more about social class and class inequalities, in which they assess their own college or university through a social justice lens - education as a basis human right, and precollege programs for applying to college and finding financial aid,

- Action Practicum, in which they participate in action projects within their own experience, such as challenging the preferences given to affluent students, or the redlining by banks which depleted the resources of their sending school.

Courses like these might comprise a curriculum of its own, or part of a program which is complementary, or a comprehensive initiative which includes summer reading programs; first-year seminars; academic advising; undergraduate research, and living-learning communities. Living-learning communities are popular, but if they do not include critical cultural content, first generation students are still left short (Brower \& Inkelas, 2010; Brower \& Kurotsuchi, 2017).

John Dewey argued that curricula have public and personal dimensions. Some courses have content which refers to our own heritage in language that is familiar to us, and others offer content which prepare us for public work in the larger community in which we share. In a society that is segregated and diverse, both types of courses should be possible (Delpit, 2006).

\section{Learning and Teaching}

First generation students want courses whose pedagogies fit their learning styles.

Each student has a preferred learning style, and "culturally responsive teaching" assumes that that learning is more effective when the teacher has cultural competencies and adapts the teaching to the culture of the students. In this approach, teachers recognize that first gens are usually low-income minorities of color who come from economically disinvested and racially segregated areas and have learning styles which fit their situation. (Adams, Bell \& Griffin, 2016; Gay, 2000; Ladson-Billings 1995).

Some educators believe that low income minorities of color learn best when they work in small groups addressing problems and issues responsive to their life experiences. This approach is often identified with "engaged learning" or "service learning" pedagogies that relate to the cultures of the students, that are problem based in which they learn about a subject through the experience of solving a problem, and that discuss real life scenarios which are familiar to them (Bonwell \& Eison, 1991; Stevens \& Levy, 2005; Yeh, 2010).

Other educators recognize the importance of engagement, but believe that learning about any topic in any discipline can be engaging if the teacher has cultural sensitivities and employs pedagogies that motivate the students. Despite its increase, service-learning is still peripheral to most disciplines for which lectures, and seminars dominate. There is no a priori reason lectures and seminars should be more engaging than service-learning for first-generation students. Indeed, it might not be the pedagogy which is the issue, but rather the professor's ability to engage students with whatever pedagogy he or she employs.

Professors should be taught to ask Big Questions, the ones that "matter to everyone and that everyone can understand." The issue here is not the so-called complexity of the concept, but rather the ability of the teacher to formulate questions that affirm all students, and do not make first-gens feel stupid (Feigelson, n.d.).

For example, an algebra teacher uses civil rights content as a vehicle for learning algebra. He brings African-American students into the gymnasium, where they discuss prejudice and discrimination un their own lives, learn about the history of the civil rights movement, and then they are ready to apply this content through activities which accelerate their understanding of algebraic equations.

Or, a physicist teaches about velocity by asking students to compare the differences in crashes between cars used by low-income and high-income drivers, Or, A mathematician teaches calculus by using Native American 
examples which are easily grasped by underrepresented students, Or, a political scientist asks why election turnout differs among ethnic groups, and am historian who teaches history to Latino students by involving them in their own neighborhoods.

At California State University at Chico, incoming first-generation students --- who are economically disadvantaged and whose parents support them by working in the fields --- learn English composition by enabling them to form small groups around a policy issue which is relevant to their lives. The students participate in research in which they gather information on the topic, write papers, and make public presentations in town halls.

These courses involve students in learning about topics through pedagogies that engage students in phenomena with which they are familiar. They make references to situations in their own lives, pose problems which they themselves face, work together in teams to gather information, and write and speak about matters which concern them. Evaluations of this "public sphere pedagogy" shows that because the pedagogy is real to the students, they grasp the topic more easily, they increase in their psychological well-being, feel more confident in themselves and their sense of civic efficacy, and affects their persistence to graduation (Wolf, 2016).

In contrast to the advocates of culturally-responsive education, some educators believe that when a pedagogy is foreign and discomforts the students beyond their usual learning edge, they also learn, sometimes more than if the teaching is familiar to them. The argument here is that students should combine both courses which are responsive to their culture and courses which are foreign, also in the spirit of a liberal education.

However, most professors are not trained in culturally-responsive teaching and learning, but rather teach how they themselves were taught. They learn to speak, and students learn to listen; they have knowledge and students acquire it. They impart information through lectures, readings, papers, and examinations. They ask the students "Do you understand the instructions?" and the students ask, "Is this what you want?"

These pedagogies are not the only ones, but they are illustrative of the ones often found in the college classroom. The more that they are used, and the more students adapt to them, the more completely students accept the passive roles ascribed to them. This is not culturally responsive teaching.

\section{Finding Professors}

First-gens want professors who are knowledgeable about their subject and available to talk with them outside of class. They want someone who will ask them about themselves, listen to them, and establish a relationship, but too few professors take time for this (Bain, 2004; Chase, 2010; Harvey, 2010); Slate, 2016).

Class differences between professors and students affect their relationships. Professors grow up in families with higher education, expect their children to attend college, have money to pay for them. They usually attend segregated schools in segregated communities, and this continues in their undergraduate and graduate years, after which they are viewed as upper-middle class by their occupational status (De Angeles, 2012; Fassinger, 1995; Fiske \& Marcus, 2012).

First generation students grow up in families without higher education or the surplus funds to pay for them. Even if they are highly motivated, college is not necessarily a realistic option. It is almost as if they and the professors come from different worlds.

First gens often speak languages which are different from professors. Studies show that by the third grade, lower income children have heard 30 million fewer words than their higher income counterparts. When lower income students meet professors, who use words that are foreign to them, this further exacerbates their cultural differences.

When professors speak in a foreign language, it can result in misunderstandings which cause students to fall short and blame themselves for their poor performance, when the problem is a cultural mismatch in which professors do not speak their language. When students say that they did not know that the paper was due, and the professor marks them down for their failure to meet the deadline, when the problem was that the professor spoke in language that the students did not understand (Collier \& Morgan, 20081 Stephens, 2010).

Most professors lack training in intergroup dialogue which might enable them to communicate with others who are different from themselves. They are not trained to discuss class and race issues which affect students, or know how to handle sensitive intercultural issues when they arise, and this exacerbates their differences.

First-gens would benefit from "education for the whole person" in which professors recognize that learning is more effective when they know something about students' personal background and social environment. But the professionalization of the professoriate places special emphasis on their discipline rather than relationships with 
students. When a professor is standing in front of the class, he or she might not realize that some students feel like foreigners in a distant land.

It is no surprise when professors call upon students of who are from the same social class as they, while first generation students sit quietly in the back, although their silence is not about their ability to speak, but rather about a social structure that silences them (Cain, 2011; Harvey, 2016; Hill, 2016; Kim \& Linda, 2009; Peetet, Montgomery \& Weeks, 2015; Young, 2016).

Research says that a close relationship with at least one professor helps students to break the isolation, feel like they belong, and contribute to completion, but amidst class inequalities, such relationships are unlike to happen (Campbell \& Campbell, 1997; Fentness \& Callopy, 2011; Harvey, 2016; Hill, 2016; Jack, 2016).

Most professors want their students to learn, but from their first days in graduate school and into their academic careers, they are conditioned to themselves know in ways which they themselves were taught. Too often they do not employ pedagogies that align with the cultural characteristics and learning styles of their students. Cook, Bovill, \& Felten, 2014; Cox, 2009)

Not all professors are distant from first generation students. On the contrary, there are exceptional professors whose doors are open. For students unfamiliar with college, however, they are too often difficult to find (Bain, 2004; Kocel, 2008; Young, 2016).

\section{Engaging Students}

First generation students should participate in the educational decisions that affect their lives. They should participate because they are experts in their roles as students, because they have information which will affect education quality, and because it is their right to do so. Some of the most significant changes in higher education have come from student participation, but here too there are class differences in student leadership roles.

At present, however, first generation students say that they come to college to "get a degree," "improve their job opportunities," "gain economic prosperity," and "help their families" (Blackwell \& Pinder, 2014; Stephens, et al., 2012). They expect to "take courses" and "work hard," but not necessarily participate in the policy or program decisions of the institution, even when the issues are central to them.

At the same time, colleges are looking for students who have high test scores and grades, challenging courses, well-written essays, extracurricular activities, and positive recommendations. They do not select them because they say that they are motivated to change the policies of the institution.

Once inside the gates, however, students can choose how to spend their time outside of class. They can choose from student government, community service, school newspaper, campus committees. They can speak up for a cause, advocate on issue, or start a group of their own.

However, studies show that lower income students participate much less than higher income students in cocurricular activities, and instead use their out-of-school time working at outside jobs, studying, sleeping, and socializing with friends (Bureau of Labor Statistics, 2016; Snellman et al., 2015).

First generation nonparticipation has various explanation. One is that there is something culturally wrong with themselves --- that they are apathetic or deficient and thus withdraw from the process. However, the "apathy of withdrawal" should not be interpreted as a cultural flaw in first gens, but rather as the "politics of displacement" in which their belief in withdrawal is the result of a consciousness promulgated and perpetuated by society. The consciousness of lower-income people is too often shaped by higher-income people who protect their own power and treat others as deficient. When "others" then "internalize the oppression" and accept the given social order, they then fulfill a "suicidal prophecy" in which they disempower themselves, in the absence of intervention to the contrary.

Community organization is a vehicle for people seeking to participate. Organizing --- in which they set their own goals, form their own groups, and take actions on the issues that concern them --- is instrumental to increasing power in society (Jehangir, 2010).

On campus, three are limitless issues around which first generation students might grain, such as increasing the number of low income minorities and stopping the discrimination in which higher income legacies are given admission references, or in which bridging programs pacify rather than activate them, or have courses and professors which are culturally inappropriate (Golden, 2006).

In the community, first generation students might challenge the decisions which create economic disinvestment and racial segregation and cause their sending schools to have the resources they need to prepare students more effectively for college. They should pressure colleges to view themselves as community development 
institutions who work with students, teachers, and parents to apply to college and find financial aid. There is nothing a priori to say that community development of this type might not become a primary purpose that is integral to the educational mission of the institution.

Community organization is not normally a priority of first generation students who are trying to make their way inside the gates of higher education to better themselves. However, there is data which demonstrates that students who enter college with civic aspirations often weaken this purpose during the college years.

It would seem strange if higher education were to weaken the civic activism of some first-generation students, but this might be the case, and there is research which reports that while entering students increasing in their interest in community service, the orientation toward political engagement is much less, and even decreases during the college years, It might seem stranger if the bridging programs designed to ease their transition were a weakening process from their first days, but this is a possibility.

Class Action --- a new organization that aims to treat first generation students with respect, support their development to their full potential, reduce the present disparities in access to resources, ensure that everyone has a voice in the decisions that affect them --- is emerging on campus, especially at small liberal arts colleges and elite private institutions. These institutions have immense resources to find the most highly qualified low-income minorities, reach out to them in their schools and communities, visit their homes and meet with their parents, to assure them that the institution will take care of them (Pappano, 2015).

It seems paradoxical that private upper-class institutions are the ones to which first generation lower income students are attracted. But these institutions are wealthy institutions whose professors and administrators are eager to recruit them, and provide financial aid beyond other institutions.

Once highly qualified low-income minorities come to campus and are brought together, they talk about their earlier experiences and what they have in common. When they become aware that their personal experiences are socially rooted, this awareness can be transformational. They often develop a class consciousness and view their experience through a class lens, organize around the class issues that concern them, and make unprecedented demands on the institution, which requires them to respond. Class consciousness is an important step for first gens to "choose success" (Macias, 2013; Peetet et al., 2015).

When colleges and universities which are challenged by brilliant lower income students who are highly conscious of social class inequalities, conflict follows. History teaches that when students are well organized, they can transform an institution.

\section{Institutional Change}

If a college or university wanted to become an institution which engages and empowers first generation students, what would it take? (Davis, 2010)

First is commitment to the purpose, affirmed by mission statements like "knowledge for society" or "education for democracy," with an image that they are accessible to all, not just a few. Then there is strategy, a process for accomplishing the purpose over the long haul, not just as a single event. Then there is structure, decisions about institutional units with responsibility for implementation, not just by hiring a person (Housel \& Harvey, 2016; Ward, Siegel \& Davenport, 2012).

However, "college for everyone" would be as unlikely to implement as would be "education for no one, no-one" and that without naming groups --- such as low-income students --- an institution will perpetuate the inequalities of a given social order. Institutional structures rarely have resources to make even a small mark on a democratic society, but they can help in launching a campaign. In the absence of any structures, however, legacies will be accepted, and first gens will be left outside the gates (DeRosa \& Dolby, 2014; Golden, 2006).

Low income minorities of color usually benefit from bridging programs designed to ease their transition - that is, to handle some of the angst they experience --- on coming through the gates of primarily white institutions. But even when services recognize strengths rather than deficits, they are still services which, while well-meaning, can disempower people.

They also will want courses which can help them to understand the social structural forces that perpetuate their subservience ---- and professors who can explain these forces in ways which are provocative enough to simulate them to challenge the present distribution of power.

It is important to reiterate that professors are strategically situated for equity and inclusion, that they play key roles in educational institutions and can employ methods that engage their students. They are not normally trained in this way, and the reward structures do not reinforce this, but faculty professional development might 
make some of them aware of the possibilities. However, professors do not usually participate in professional development when they are in their institutional roles.

It is conceivable that the rarest of authorities might try to get professors in a room to remediate them, but this would challenge their socialization into the professoriate, which would be more powerful than institutional rewards once they are in their jobs. Changing graduate school and professional socialization would take changes in their disciplines and fields too. When authorities propose changes in this entire structural system, however, it evokes counterforce by those who have been socialized into the system.

Equity and inclusion require community participation in various ways. First, they require long-term school and community partners who can support students in applying to college. Second, campaigns about expanding access to higher education faces political forces so powerful that even the strongest advocates stop trying, until new generation of advocate come along and try again.

Changing the culture of universities requires cultural campaigns which will include presidents, executive officers, deans and department heads, and intellectual leaders and change agents among the faculty. Such efforts require leadership that is not normal at present, but there are institutions from which to learn.

Students have more potential power than they realize. They can unite as a group, take formal positions, and pressure professors and administrators. History shows that students can stimulate institutional changes. At present, however, student leaders normally come from legacies who aspire to entering the system rather than changing it, which is also the case for most minorities. When minorities arise and challenge institutions, they usually evoke responses, which require resources which are managed by authorities with commitment to the status quo.

\section{Inside The Gates}

This paper examines what first-generation students face when coming inside the gates of higher education for the first time. This experience can cause a level of anxiety which affects their learning, unless they and the institution are prepared.

The paper includes some of what they experience, such as choosing courses whose content is relevant to their social situation, and finding professors who can communicate with them in language which they understand.

US society is changing, and it will not be long before people of African, Asian, and Latin American descent will become the majority. First generation low income and minority students of color are increasing in higher education, and they too will become the majority. These changes are challenging institutions to rebuild their capacity for the future.

It is possible to imagine a university whose mission is "equity, inclusion and educational excellence," and whose courses and pedagogies are responsive to all students, not just a few. It is possible to imagine professors who are both knowledgeable about their subjects and approachable by all students, not just a few. It also possible to imagine a university whose students step forward and organize for social and political around a new vision of the institution

It is possible to imagine these things. But because they are imaginable does not make them so, and the obstacles against them are formidable indeed.

It is difficult to imagine fundamental changes in colleges and universities whose members view first generation students as deficits, plan programs without involving them, and do not share their power with others. It is difficult when students accept others' definition of them and "internalize the oppression" of officials and the limitations that they place upon them. It is difficult when students question their own legitimacy, do not view themselves as a cohesive group, and are not organized enough for real influence.

Indeed, colleges and universities are anchor institutions in a larger society which is shaped by structure which respond to present powerholders, who are not lower income minorities of color. Once first-generation students come inside the gates in large numbers and become the majority, it will surface some of the most intractable issues in society, for which many institutions are unprepared.

It is difficult to imagine fundamental changes in institutions whose present participants are deeply invested in the status quo. But if the world could undergo a change in basic assumptions from the Ptolemaic model of the heavens, which described the cosmos as having Earth stationary at the center of the universe, to the heliocentric model with the Sun at the center of the Solar System, then surely it is possible for colleges and universities to change their views of their students. 


\section{References}

Ackermann, S. P. (1991). The benefits of summer bridge programs for underrepresented and low transfer students. Community /Junior College Quarterly of Research and Practice, 15, 211-224. https://doi.org/10.1080/0361697910150209

Adams, M., Bell, L. A., \& Griffin, P. (2016). Teaching for Diversity and Social Justice. New York: Routledge.

Alessandria, K. P., \& Nelson, E. S. (2005). Identity development and self-esteem of first generation American college students: An exploratory study. Journal of College Student Development, 46, 3-12. https://doi.org/10.1353/csd.2005.0001

Atherton, M. C. (2014). Academic preparedness of first-generation college students: Different perspectives. Journal of College Student Development, 55, 824-829. https://doi.org/10.1353/csd.2014.0081

Atkinson, R., \& Longman, D. (2015). Choosing Success. New York: McGraw Hill.

Baldwin, A. (2011). The First-Generation College Experience. Boston: Pearson Education.

Blackwell, E., \& Pinder, P. J. (2014). What are the motivational factors of first-generation minority college students who overcome their family histories to pursue higher education? College Student Journal, 48, 45-56.

Brower, A., \& Kurotsuchi, K. (2017). Living-learning programs: One high-impact educational practice we now know a lot about. Liberal Education, 96, 36-43.

Cabrera, N., Miner, D., \& Milam, J. (2013). Can a summer bridge program impact first-year persistence and performance? A case study of the New Start Summer Program. Research in Higher Education, 54, 481-498. https://doi.org/10.1007/s11162-013-9286-7

Cain, S. (2012). Quiet: The Power of Introverts in a World That Can't Stop Talking. New York: Random House.

Campbell, T., \& Campbell, D. (1997). Faculty/student mentor program: Effects on academic performance and retention. Research in Higher Education, 38, 727-742. https://doi.org/10.1023/A:1024911904627

Clauss-Ehlers, C. S., \& Wibrowski, C. R. (2007). Building Educational Resilience and Social Support: The Effects of the Educational Opportunity Fund Program Among First- and Second- Generation College Students. Journal of College Student Development, 48, 574-584. https://doi.org/10.1353/csd.2007.0051

Collier, P. J., \& Morgan, D. L. (2008). Is that paper really due today? Differences in first-generation and traditional college students' understandings of faculty expectations. Higher Education: The International Journal of Higher Education and Educational Planning, 55, 425-446. https://doi.org/10.1007/s10734-007-9065-5

Cook-Sather, A., \& Bovill, C., \& Felten, P. (2014). Engaging Students as Partners in Learning and Teaching. San Francisco, CA: Jossey-Bass.

Covarrubias, R., Romero, A., \& Trivelli, M. (2015). Journal of Child and Family Studies, 24, 2031-2037. https://doi.org/10.1007/s10826-014-0003-8

Davis, J. (2010). The First-Generation Student Experience: Implications for Campus Practice, and Strategies for Improving Persistence and Success. Sterling: Stylus.

Delpit, L. (2006). Other People's Children: Cultural Conflict in the Classroom. New York: Free Press.

Dennis J. M., Phinney J. S., \& Chuateco L. I. (2005). The role of motivation, parental support, and peer support in the academic success of ethnic minority first-generation college students. Journal of College Student Development, 46, 223-236. https://doi.org/10.1353/csd.2005.0023

DeRosa, E., \& Dolby, N. (2014). I don't think the university knows me: Institutional culture and lower-income, first-generation college students. InterActions, 10(2), Retrieved from: http://escholarship.org/uc/item/0kj6m6r8. Google Scholar

DeWalt, P. (2011). Attending a preliminary white institution. Journal of Black Studies, 42, 479-50.

Duckworth, A. L., Peterson, C., Matthews, M. D., \& Kelly, D. R. (2007). Grit: Perseverance and passion for long-term goals. Journal of Personality and Social Psychology, 92, 1087-1101. https://doi.org/10.1037/0022-3514.92.6.1087

Fentress, J., \& Callopy, R. (2011). Promoting resiliency among first-generation college students. The Mentor: An Academic Advising Journal. Retrieved from 
https://dus.psu.edu/mentor/2011/02/resiliency-among-first-generation-students/

Banks-Santilli, L. (2014). First-generation college students and their pursuit of the American dream. Journal of Case Studies in Education, 5. Retrieved from http://www.aabri.com/manuscripts/131657.pdf

Garrison, N. G., \& Gardner, D. S. (2012). Assets first generation college students bring to the higher education setting.

Gay, G. (2000). Culturally Responsive Teaching: Theory, Research, and Practice. New York: Teachers College Press.

Ghazzawi, I., \& Jaggannathan, C. (2011). Bridging the gap: The role of outreach programs in granting college access to first generation students. Academy of Educational Leadership, 15, 117-137

Gibbons, M. M., Rhinehart, A., \& Hardin, E. (2016). How First-Generation College Students Adjust to College. Journal of College Student Retention: Research, Theory \& Practice. Retrived from https://doi.org/10.1177/1521025116682035

Golden, D. (2006). The Price of Admission: How America's Ruling Class Buys Its Way into Elite Colleges - and Who Gets Left Outside the Gates. New York: Crown Publishers.

Greene, D. M. (2016). Effort helps first-generation students at U-M meet challenges. The University Record Retrieved from https://record.umich.edu/articles/effort-helps-first-generation-students-u-m-meet-challenges

Harvey, V. (2011). Faculty, and First-Generation College Students: Bridging the Classroom Gap Together: New Directions for Teaching and Learning, Higher Education, 55, 425-446.

Hill, T. (2016). Navigating Campus Together First-generation faculty can steer first-generation college students toward success. Atlantic Magazine. May, n.p.

Housel, T. H., \&Harvey, V. (2016). (Ed.) The First-Generation Student Experience: Implications for Campus Practice, Sterling: Stylus Publishing.

Hrabowski, III, F. A. (2005). Fostering first-year success of underrepresented minorities. In M. L. Upcraft, J. N. Gardner, \& B. O. Barefoot, eds. Challenging and Supporting the First-Year Student: A Handbook for Improving the First year of College. San Francisco: Jossey-Bass.

Inkelas, K. K., Daver, Z., Vogt, K., \& Leonard, J. B. (2007). Living-learning programs and first-generation college students' academic and social transition to college. Research in Higher Education, 48, 403-434. https://doi.org/10.1007/s11162-006-9031-6

Inman, E. W., \& Mayes, L. D. (1999). The importance of being first: Unique characteristics of first-generation community college students. Community College Review, 17, 48-52. https://doi.org/10.1177/009155219902600402

Ishitani, T. F. (2006). Studying attrition and degree completion behavior among first-generation college students in the United States. Journal of Higher Education, 77, 861-885. https://doi.org/10.1353/jhe.2006.0042

Jack, A. A. (2016). (No) Harm in asking: Class, acquired cultural capital, and academic engagement at an elite university. Sociology of Education, 89, 1-19. https://doi.org/10.1177/0038040715614913

Jehangir, R. R. (2010). Higher Education and First-Generation Students: Cultivating Community, Voice, and Place for the New Majority. New York: Palgrave Macmillan. https://doi.org/10.1057/9780230114678

Kahlenberg, R. D. (2004). America's Untapped Resource: Low-Income Students in Higher Education. New York: Century Foundation Press.

Kim, Y. K., \& Sax, L. J. (2009). Student-faculty interaction in research universities: Differences by student gender, race, social class, and first-generation status. Research in Higher Education, 50, 437-459. https://doi.org/10.1007/s11162-009-9127-x

Kocel, C. K. (2008). Advising first-generation college students for continued success. The Mentor: An Academic Advising Journal, 10, 1-4.

Ladson-Billings, G. (1995). Toward a theory of culturally relevant pedagogy. American Educational Research Journal, 32, 465-91. https://doi.org/10.3102/00028312032003465

Leondar-Wright, B. (2005-07). Are There Class Cultures? Gabriolla Island: New Society Publishers.

Leondar-Wright, B. (2005). Class Matters: Cross-Class Alliance Building for Middle-Class Activists. Gabriolla Island: New Society Publishers 
Leondar-Wright, B. (2013). Pretense, Putdowns, and Missing Identities in Activists' Class Talk. Humanity \& Society, 37, 225-247. https://doi.org/10.1177/0160597613495842

Leondar-Wright, B. (2014). Missing Class: Strengthening Social Movement Groups by Seeing Class Cultures. Ithaca: Cornell University Press.

Leondar-Wright, D. (2004). Dilemmas of Community Organizers. Class Matters. Retrieved from http://www.classmatters.org/2004_04/dilemmas_of_comm_orgs.php

Leotard, J. (1997). The Postmodern Condition: A Report on Knowledge. Minneapolis: University of Minnesota Press.

Lohfink, M. M., \& Paulsen, M. B. (2005). Comparing the determinants of persistence for first-generation and continuing-generation students. Journal of College Student Development, 46, 409-248. https://doi.org/10.1353/csd.2005.0040

Macias, L. V. (2013). Choosing success: A paradigm for empowering first-generation college students. About Campus, 18, 17-21. https://doi.org/10.1002/abc.21133

Martin, M., \& Paulsen, M. B. (2005). Comparing the determinants of persistence for first-generation and continuing- generation students. Journal of College Student Development, 46, 409-428. https://doi.org/10.1353/csd.2005.0040

Mehta, S. S., Newbold, J. J., \& O'Rourke, M. A. (2011). Why do first-generation students fail? College Student Journal, 45, 20-35.

Moore, R. S., et al. (2007). Developing an intervention bridging program for at-risk students before the traditional pre-freshman summer program. College Student Journal, 41, 151-159.

Padgett, R. D., Johnson, M. P., \& Pascarella, E. T. (2012). First-generation undergraduate students and the impacts of the first year of college. Journal of College Student Development, 53, 243-266. https://doi.org/10.1353/csd.2012.0032

Pappano, L. (2015). First-generation students unite. The New York Times, April 12: ED18.

Pascarella, E. T., Pierson, C. T., Wolniak, G. C., \& Terenzini, P. T. (2004). First-generation college students: Additional evidence on college experiences and outcomes. Journal of Higher Education, 75, 249-284. https://doi.org/10.1080/00221546.2004.11772256

Peetet, B. J., Montgomery, L., \& Weekes, J. C. (2015). Predictors of imposter phenomenon among talented ethnic minority undergraduate students. The Journal of Negro Education, 84, 175-186. https://doi.org/10.7709/jnegroeducation.84.2.0175

Quaye, S. J. \& Harper, S. (2015). Student Engagement in Higher Education: Theoretical Perspectives and Practical Approaches for Diverse Populations. New York: Routledge

Rendon, L., \& Muñoz, S. (2011). Revisiting Validation Theory: Theoretical Foundations, Applications, and Extensions. Enrollment Management Journal, 3, 12-34.

Rendon, L. (1994). Validating Culturally Diverse Students: Toward a New Model of Learning and Student Development. Innovative Higher Education, 16, 33-43. https://doi.org/10.1007/BF01191156

Rice, A. J. et al., (2017). The social class worldviews of first-generation college students Counselling Psychology Quarterly, 30, 1-26. https://doi.org/10.1080/09515070.2016.1179170

Rice, A. J., Colbow, A. J., Gibbons, S., Cederberg, C., Sahker, E., ... Liu, W. M. (2007). First in My Family: A Profile of First-Generation College Students at Four-Year Institutions Since 1971. Los Angeles: Higher Education Research Institute.

Schultz, P. F. (2004). Upon entering college: First semester experiences of first-generation, rural students from agricultural families. Rural Educator, 26, 48-51.

Snellman, K., Silva, J. M., Frederick, C. B., \& Putnam, R. D. (2015). The engagement gap: Social mobility and extracurricular participation among American youth. Annals of the American Academy of Political and Social Science, 657, 194-207. https://doi.org/10.1177/0002716214548398

Somers, P., Woodhouse, S. R., \& Cofer, J. E. (2004). Pushing the boulder uphill: The persistence of first-generation college students. Journal of Student Affairs Research and Practice, 41, 811-828. https://doi.org/10.2202/1949-6605.1353 
Stephens, N. M. (2012). .A cultural mismatch: Independent cultural norms produce greater increases in cortisol and more negative emotions among first-generation college students. Journal of Experimental Social Psychology, 48, 1389-1393. https://doi.org/10.1016/j.jesp.2012.07.008

Stephens, N. M., Fryberg, S. A., Markus, H. R., Johnson, C. S., \& Covarrubias, R. (2012). Unseen disadvantage: how American universities' focus on independence undermines the academic performance of first-generation college students. Journal of Personality and Social Psychology, 102, 1178-1197. https://doi.org/10.1037/a0027143

Stephens, N. M., Hamedani, M. G., \& Destin, M. (2014). Closing the social-class achievement gap A difference-education intervention improves first-generation students' academic performance and all students' college transition. Psychological Science, 25, 943-953. https://doi.org/10.1177/0956797613518349

Stevens, D. D., \& Levi, A. (2005). Leveling the Field: Using Rubrics to Achieve Greater Equity in Teaching and Grading. Essays on Teaching Excellence, Professional and Organizational Development Network in Higher Education, 17(1).

Stevens, D. D., \& Levi, A. J. (2005). Leveling the field: Using rubrics to achieve greater equity in teaching and assessment. Essays on Teaching Excellence, Professional and Organizational Development Network in Higher Education, 17, 1-30.

Strayhorn, T. (2009). An Examination of the Impact of First-Year Seminars on Correlates of College Student Retention. Journal of The First-Year Experience \& Students in Transition, 21, 9-21.

Strayhorn, T. L. (2010). Bridging the pipeline: Increasing underrepresented students' preparation for college through a summer bridge program. American Behavioral Scientist, 55, 142-159. https://doi.org/10.1177/0002764210381871

Swiencicki, J., Fosen, C., Burton, S., Gonder, J., \& Wolf, T. (2011). The town hall meeting: Imagining a self through public-sphere pedagogy. Liberal Education, 97, 40-45.

Tibbetts, Y., Harackiewicz, J. M., Canning, E. A., Boston, J. S., Priniski, S. J., \& Hyde, J. S. (2016). Affirming independence: Exploring mechanisms underlying values affirmation intervention for first-generation students. Journal of Personality and Social Psychology, 110, 635-659. https://doi.org/10.1037/pspa0000049

Unverferth, A. R., Talbert-Johnson, C., \& Bogard, T. (2012). Perceived barriers for first-generation students: Reforms to level the terrain. International Journal of Educational Reform, 21, 238-252.

Wang, T. R. (2012). Understanding the memorable messages first-generation college students receive from on-campus mentors. Communication Education, 61, 335-357. https://doi.org/10.1080/03634523.2012.691978

Ward, L, Siegel, M. J. \& Davenport, Z. (2012). First-Generation College Students: Understanding and Improving the Experience from Recruitment to Commencement. San Francisco: Jossey Bass.

Warnock, D. M., \& Hurst, A. L. (2016). The poor kids' table: Organizing around an invisible and stigmatized identity in flux. Journal of Diversity in Higher Education, 9, 261-276. https://doi.org/10.1037/dhe0000029

Willie-LeBreton, S. (2016). Transforming the Academy: Faculty Perspectives on Diversity and Pedagogy. New Brunswick: Rutgers University Press.

Wolf, T. (2016). Public sphere pedagogy: Engaging students as participants in democracy. Diversity \& Democracy, 17.

Woosley, S. A., Sherry, A., \& Shepler, D. K. (2012). Understanding the early integration experiences of first-generation college students. Journal of Postsecondary Education and Disability, 25, 37-50.

Yosso, T. J. (2005). Whose culture has capital? Race, Ethnicity, and Education, 8, 69-91.

\section{Copyrights}

Copyright for this article is retained by the author(s), with first publication rights granted to the journal.

This is an open-access article distributed under the terms and conditions of the Creative Commons Attribution license (http://creativecommons.org/licenses/by/4.0/). 